\title{
Detrital zircon records of Late Cretaceous syn-rift sedimentary sequences of New Caledonia: an Australian provenance questioned.
}

Dominique Cluzel $^{1}$, Christopher J. Adams ${ }^{2}$, Pierre Maurizot ${ }^{3}$, and Sébastien Meffre ${ }^{4}$.

${ }^{1}$ Pôle Pluridisciplinaire de la Matière et de l'Environnement, EA 3325, Université de la Nouvelle-Calédonie, BP R4, 98851 Nouméa Cedex, New Caledonia, and Institut des Sciences de la Terre d’Orléans, Unité Mixte de Recherche 6113, CNRS/Université d’Orléans, 1A rue de la Férollerie, 45071 Orléans Cedex 2, France. (dominique.cluzel@univnc.nc)

${ }^{2}$ GNS Science, Private Bag 1930, Dunedin, New Zealand.

${ }^{3}$ Bureau de Recherches Géologiques et Minières, and Direction de l'Industrie, des Mines et de l’Energie, B.P. 465, 98845 Nouméa, New Caledonia.

${ }^{4}$ Australian Research Council Centre of Excellence in Ore Deposits, University of Tasmania, Hobart Campus, Private Bag 79 Hobart Tasmania 7001.

\footnotetext{
Abstract

The Late Cretaceous clastic coastal sediments of New Caledonia are contemporaneous with the latest stages of the eastern Australian marginal rifting. As such, they record the erosion of basement terranes located on uplifted and tilted blocks and a contemporaneous volcanic activity. Detrital zircon populations contain two major components, the younger of which is Early Cretaceous, and the older Early Paleozoic and Precambrian. Following recent advances in the knowledge of detrital zircon content of basement terranes, and at variance with previous interpretations, that hypothesised a possible direct Australian provenance for Precambrian zircons, the detrital zircon record of these syn-rift sediments allows a local recycled provenance to be established. In consequence, this new evidence confirms that New Caledonia was already isolated from Australia as early as Coniacian time (ca. 89-85 Мa) a fact consistent with the development of faunal and floral endemism at that period. The prominent abundance of Early Cretaceous detrital zircons also establishes the importance of a previously unrecorded Early Cretaceous magmatism in the area.
}

\section{Keywords}

Late Cretaceous, New Caledonia, Southwest Pacific, provenance, detrital zircon, U-Pb geochronology, endemism. 


\section{Introduction.}

The Late Cretaceous is a period of major changes in New Caledonia where the end of the Late Paleozoic-Mesozoic active margin evolution was closely followed by the opening of several Late Cretaceous (Campanian, ca. 83.5 Ma) to Late Paleocene (ca. $55 \mathrm{Ma}$ ) marginal basins (Tasman Sea, New Caledonia, and South Loyalty basins), which isolated elongated slices of the former Australian margin. These continental stripes of thinned continental crust now form, in the major part, Zealandia, or preferably, in total, Zealonia (from New Zealand and New Caledonia), a continent-size set of largely submarine highs and plateaus: the Lord Howe Rise, Challenger Plateau, Norfolk Ridge, Campbell Plateau and Chatham Rise (Fig. 1), the emerged parts of which forms present-day New Zealand and New Caledonia (Gaina et al., 1998a, 1998b; Hall, 2002). This view is supported by the many geological features which are shared by New Zealand and New Caledonia, and especially their Mesozoic faunal endemism (Wilckens, 1925; Grant-Mackie et al., 1977; Collignon, 1977; Freneix, 1980, 1981). Meanwhile, sedimentation changed markedly in New Caledonia in Late Cretaceous times. The deep water volcaniclastic turbidites (commonly referred to as greywackes) and mélange which were formed in a fore-arc region (Cluzel \& Meffre, 2002) from Triassic to mid-Cretaceous time (Adams et al., 2009; Cluzel et al., 2010), changed to ConiacianSantonian (early Late Cretaceous) unconformable coal-bearing sandstone accumulated in a marine deltaic environment. The sandstones are conformably overlain by Campanian-Early Maastrichtian carbonaceous siltstone; this change was synchronous with the onset of oceanic accretion in the Tasman Sea and South Loyalty marginal basins. Sedimentation continued during the Late Maastrichtian-Early Paleocene with pelagic chert-like "phtanite", and Late Paleocene to mid-Eocene micrite deposited throughout the area (see Cluzel et al., 2001 and references therein). The Late Cretaceous sandstones accumulated during the syn-rift period; whilst Paleogene pelagic sediments may be related to the post-rift period (Aitchison et al., 1995a). A very similar sequence of events is recorded by sedimentary rocks of the same age in New Zealand (see Laird \& Bradshaw, 2004; Mortimer, 2004 and references therein). Whether New Caledonia and New Zealand were still connected to Australia at that time by land bridges remains uncertain. The abundant Early Cretaceous and Precambrian zircon populations in sandstone led previous authors to conclude that some clastic material originated in Australia (Aronson and Tilton, 1971; Aitchison et al., 1998) because magmatic rocks of that age do not occur in New Caledonia. However, this conclusion has been recently questioned by the discovery of Early Cretaceous "greywackes" (Cluzel et al., 2010), which are a possible source for recycled zircons of this age. In addition, large amounts of 
Precambrian zircons have been found in sandstones of some basement terranes of New Caledonia (Cluzel \& Meffre, 2002; Adams et al., 2009; Cluzel unpubl. data) which could thus be a local source. Moreover, an Australian connection is questionable because Late Cretaceous marine fossils, especially inocerams, trigonids and other bivalves, for a long time have been considered endemic (Freinex, 1980, 1981), as well as most fossil plants (Crié, 1888; Zeiller, 1889) thus suggesting isolation from Australia at that time.

This study is focused on the Late Cretaceous autochthonous sediments classically referred to as "Formation à charbon" which probably accumulated during the rifting of Australian margin, before the opening of Campanian marginal basins, which eventually separated New Caledonia and Australia. In this paper, we present new detrital zircon data from eleven sandstone and meta-sandstone samples collected along the island (Fig. 1) and we explore their possible provenance; this new dataset allows an alternative interpretation and a comparison with coeval sediments of New Zealand to be proposed.

\section{Late Cretaceous rocks in New Caledonia.}

Late Cretaceous rocks are found in New Caledonia in three autochthonous and allochthonous units which probably represent components of the Late Cretaceous eastern margin of the Norfolk Ridge; i.e., the easternmost known part of the Australian margin:

a) Autochthonous units form the unconformable cover upon pre-Late Cretaceous terranes; these shallow marine sediments started accumulating in Coniacian time upon the "continental" New Caledonian part of the Norfolk Ridge (Paris, 1981)

b) The parautochthonous Koné Formation (or Terrane), consists of Campanian hemipelagic sedimentary rocks (Carroué, 1972), probably accumulated in a deep-sea fan offshore northeast New Caledonia.

c) The Poya Terrane is formed of allochthonous slices of oceanic crust rocks and Campanian to Early Eocene bathyal sediments, which originated in the South Loyalty marginal basin, located to the northeast of the Norfolk Ridge. These slices were thrust onto the northern tip of the ridge in Late Eocene time (Cluzel et al., 2001).

\subsection{Autochthonous sedimentary cover.}

Coniacian to Maastrichtian sediments are widespread in New Caledonia where they form the relatively thin unconformable cover of eroded Permian to mid-Cretaceous basement terranes. Extensive outcrops of these rocks occur in the Noumea (south) and Diahot regions (north of New Caledonia), because of Tertiary reclined folding and duplexing (Noumea), or 
isoclinal folding and ductile thrusting (Diahot) (Fig 1). Due to tectonic complexity, no complete section actually exists and an accurate stratigraphic sequence of the Late Cretaceous rocks is difficult to establish, in spite of their marine and fossiliferous character (see Paris, 1981; and Maurizot et al., 1989). In turn, conformable Paleocene to Eocene pelagic sediments overlie Late Cretaceous rocks.

\subsection{Formation de Koné}

Discrete slices of a parautochthonous Late Cretaceous (Campanian) hemi-pelagic unit composed of siltstone, argillite and chert, referred to as the Formation de Koné (Carroué, 1972; Paris, 1981) occur near Koné and Koumac (Fig. 1). The unit has no known basement, contains no carbonaceous material, and has more distal facies than the typical autochthonous rocks of the same age. Currently, it is situated above Paleocene autochthonous sediments and below the allochthonous Poya Terrane and has everywhere faulted boundaries. It possibly originated on a continental slope, or directly upon older oceanic crust, to the north-east of New Caledonia and was picked up and thrust upon New Caledonia by the Poya Terrane and was finally overthrust by the latter. Siltstones of the Formation de Koné are too fine grained for detrital zircons to be extracted.

\subsection{Poya Terrane}

This mafic allochthon is composed of sliced basalt, dolerite, and bathyal sediments, which represent remnants of the South Loyalty Basin crust (see Cluzel et al., 2001). These oceanic crust rocks have been erupted to form an oceanic floor to the east of present-day New Caledonia. Red chert and argillite, which are closely associated with pillow basalt contain Campanian to latest Paleocene or earliest Eocene radiolarians (Aitchison et al., 1995b; Cluzel et al., 2001). The Poya Terrane rocks have been first scraped off the downgoing plate during east-dipping subduction, then accreted to the fore-arc region of the Loyalty Arc; and thereafter thrust onto New Caledonia during the Late Eocene, prior to the obduction of ultramafic rocks (Cluzel et al., 2001).

\section{Formation à charbon, lithology and geologic setting.}

\subsection{Noumea area}

Within the Late Cretaceous sedimentary sequence of the Noumea area, two members have been distinguished on the basis of lithology and fossil content (Fig. 2). The lower member is represented by the siliclastic and volcaniclastic Formation à charbon; it is 
composed of conglomerate, sandstone with coal seams, and coaly siltstone which commonly contain bivalves (inocerams and trigonids), brachiopods, and plant remains. Ammonites found near the base of the lower member have been correlated to the middle and upper Coniacian (ca. 88-86 Ma; Collignon, 1977); a Coniacian age for the base of transgression is confirmed by the U-Pb zircon age of an interbedded rhyolite flow (88.4 Ma; Alexander et al., 2010), thus accurately dating the Late Cretaceous transgression. It seems that the bulk of coal has been carried from emerged land into the basin by streams, because most plant fossils such as Alnus (Zeiller, 1889) are diagnostic of terrestrial, i.e. stream bank environments; however, diagenetic concretions, probably due to microbial activity, occur locally within carbonaceous argillite/siltstone, and were likely formed in a coastal swamp. The local occurrence of intrabasinal clasts, intraformational breccia and clastic dykes in the Formation à charbon suggests some tectonic instability related to intrabasinal faulting. The basin is relatively homogeneous but the basal conglomerate increases north-eastwards suggesting that the Noumea basin was probably a half-graben controlled by a NW-SE trending fault. In the central part of the island, the transgression is slightly younger as indicated by the occurrence of proximal sandstone that contains gastropod fossils and rare Santonian ammonites at the base of the sequence (Paris, 1981). This suggests that it formed the uplifted part of a tilted block. Bimodal volcanic rocks occur throughout the Coniacian-Santonian part of the sequence and include mafic tuffs, volcaniclastic breccia, rare lava flows (Paris, 1981) and shallow intrusive rocks that display a clear volcanic-arc geochemical signature (Cluzel et al., 2010; Nicholson, unpubl. data). In contrast, rhyolitic pyroclastic flows (ignimbrite) belong to the alkaline series. All display evidence for contamination by continental crust rocks (Cluzel et al., 2010; Nicholson, unpubl. data). These geochemical features suggest that the rocks were formed during the thinning of continental crust in a supra-subduction or "postcollisional“environment (e.g. subduction reactivation following crustal thickening). The upper member completely lacks volcanic rocks, and is mainly composed of pyrite-rich carbonaceous siltstone and argillite indicative of a restricted or anoxic marine environment. Fossiliferous nodules near the top of the sequence contain Campanian and Maastrichtian ammonites (Collignon, 1977). Such features that suggest seawater stratification and an increasing depth through time are similar to that of basins controlled by tilted blocks in a passive margin.

\subsection{Diahot Terrane}


The Diahot terrane forms a large part of the Eocene high-pressure metamorphic complex of northern New Caledonia (Fig. 1) (Brothers and Blake, 1972). In this terrane, Late Cretaceous rocks have been metamorphosed to eclogite or blueschist facies, and commonly display prominent ductile deformation and recrystallisation (Clarke et al., 1997; Cluzel et al., 2001), so that original features (both sedimentary and magmatic) have been partly erased. According to Espirat (1963) and Maurizot (1989), two lithologic units may be distinguished within Late Cretaceous rocks in this area; they are: i) the Tondo Formation, and ii) the Pilou Formation. The Tondo Formation mainly consists of metamorphosed and schistose carbonaceous mudstone, associated with some siltstone, fine grained sandstone and very rare conglomerate. The Pilou Formation that has provided Santonian to Campanian inocerams (Paris, 1981), is thought to be younger than the Tondo formation but there is actually no clear evidence for this. It consists of monotonous pyrite-rich carbonaceous schist associated with mafic and felsic volcanic rocks metamorphosed into the blueschist facies. However, mafic boudins in highly sheared blue- or green-schist occasionally contain eclogite facies minerals (Fitzhebert et al., 2005) which suggest that the peak metamorphic grade was very high. Small-scale stratiform polymetallic sulphide ore deposits $(\mathrm{Cu}-\mathrm{Pb}-\mathrm{Zn})$ occur whithin the Pilou schist and felsic volcanic rocks. These were actively mined in the late 19th Century and have characteristics reminiscent of Kuroko type (or arc-related volcanogenic massive sulphide) deposit. Mafic volcanic rocks are dominantly arc-related, but minor alkaline rocks also exist (Picard, 1995), a feature which suggests that either the Diahot Terrane was formed upon a thinned lithosphere under the influence of an active subduction (back-arc setting); or alternatively, that a metasomatised mantle source inherited from the Permian-Mesozoic active margin evolution remained below New Caledonia when the latter was rifted from the Lord Howe Rise.

The Late Cretaceous terrigenous sequences in both regions display a bulk upwards thinning and a gradational transition with the deposition of "Phtanites" (siliceous sediments and minor argillite) in the Late Maastrichtian-Paleocene and chert-and-micrite in the Early to mid-Eocene (Fig. 2). Thus, the Late Cretaceous rocks likely represent a syn-rift sequence, whilst post-Cretaceous pelagic sedimentary rocks record the post-rift thermal subsidence (Aitchison et al., 1995a).

In the Lord Howe Rise the Late Maastrichtian radiolarian-bearing gray and black chert sampled at the base of DSDP 207 and 208 (Burns et al., 1973) overlie slightly tilted older terranes on the FAUST 2 seismic lines (Van de Beuque, 1999). This suggests that post-rift thermal subsidence on the Lord Howe Rise occurred at about the same time as in New 
Caledonia. Data from the Whangai Formation in New Zealand (Moore et al., 1988) also shows this same regional fining upwards sequences consistent with "oceanisation" of marginal basins during the Campanian. Therefore, a provenance study of clastic material that accumulated in New Caledonia during the Coniacian-Santonian provides reliable constraints on the rifting process in this part of the Southwest Pacific.

\section{Methods}

Provenance study based upon mineral or lithic clastic material only is difficult because an accurate identification of the source rock is not always possible. In contrast, detrital zircon grains because of their high resistance to abrasion are a prominent component of mediumgrain clastic rocks. Zr-U substitution and the absence of initial $\mathrm{Pb}$ in the zircon crystal lattice allow zircons be used for $\mathrm{U}-\mathrm{Pb}$ chronology, thus providing precise $(1 \sigma=\mathrm{ca} .1$ to $4 \%)$ and accurate time constraints for crystal growth. In this study the laser inductively coupled mass spectrometry (ICPMS) method was used to obtain the age of 30 micron spots on zircon crystals picked from heavy mineral concentrates. This technique is now well established for obtaining the age of single zircon crystals in igneous, sedimentary and metamorphic rocks (Refs). Although the technique is not as precise as solution based mass spectrometry, its small spatial resolution and rapid analysis (1-3 minute) makes it ideal for investigating detrital zircon in sedimentary rocks. Ten of the samples were processed and analysed at University of Tasmania (Hobart), and one (NCAL 24) at Macquarie University (Sydney). Both of these laboratories use similar equipment (Agilent 7500 cs quadrupole ICPMS in conjunction with UV lasers), techniques and standards to determine the $\mathrm{Pb}, \mathrm{U}$ and $\mathrm{Th}$ isotopic composition of zircons (see appendix 1).

\section{Detrital zircon data}

Eleven sandstone samples have been processed for detrital zircon dating, they have all been collected near the base of the Fm. à charbon and are Coniacian-Santonian with one exception: a Campanian carbonaceous siltstone (BOUR 13) collected in the upper part of the formation about 20m below the boundary with "Phtanites" at Col de Boghen (Loc. 3; Fig. 1).

As all samples except one have roughly the same Coniacian-Santonian age and similar sedimentary facies, they may be initially evaluated as a single group. The majority of the U$\mathrm{Pb}$ age of the 484 zircon crystals analysed from the 11 samples (Fig. 3) were Cretaceous in age (130-85 Ma) (67\%). Late Paleozoic and Early Mesozoic zircons were less abundant (9\%) as were Early Paleozoic to Precambrian zircons (23\%). It is worth noting that the two most 
important zircon populations (Cretaceous and Precambrian) (i.e., 90\%) relate to rocks which are apparently absent (Precambrian) or poorly represented (Cretaceous) in New Caledonia.

The composite Cretaceous zircon population (Fig. 4) consists of eight sub-populations at 78, 88, 94, 101, 104, 115, 119, and 130 Ma respectively (Table 2). The youngest zircon populations (78 Ma for the Campanian sample, and 88 Ma for the rest) are close to the assumed fossil age and zircon grains probably derive from contemporaneous magmatic activity. This interpretation is supported for the Coniacian-Santonian samples by the U-Pb zircon ages of a rhyolite flow dated at 88.4 Ma in the Noumea area (Alexander et al., 2010), and a meta-volcanic leucocratic gneiss of the Diahot terrane at $83.0 \pm 2.0 \mathrm{Ma}$ (this study; Appendix II). The older Cretaceous zircon populations are generally similar to those described by Adams et al. (2009) and Cluzel et al. (2010) and may derive from locally eroded volcaniclastic turbidites of the same age. However, such a large Cretaceous population sharply contrasts with the scarcity of possible source rocks, unless they have been eroded away before Coniacian time. Alternatively, it is possible that some of the Cretaceous zircons have been derived from syn-rift volcanic rocks similar to those of the Whitsunday Province of Eastern Australia (Ewart et al. 1992; Bryan et al., 1997) and coeval rocks in New Zealand and on the Lord Howe Rise (Tulloch et al., 2009). Distinguishing zircons derived from volcanic-arc magmatic rocks from those derived from rift-related rocks is not possible; therefore, the discussion has to be based upon different grounds.

The Permian-early Mesozoic population which is actually the smallest, has timeequivalents in volcanic or volcano-sedimentary rocks in local basement terranes and thus may be locally derived; but in contrast, there are no known outcrops of Precambrian rocks to account for the prominent Precambrian zircon populations. These must have either a direct but remote origin (the "classical" hypothesis); or alternatively, a local but recycled origin from underlying basement terranes.

In more detail, the zircons populations in Late Cretaceous sandstones can be subdivided into two types of patterns; about half display a prominent Cretaceous population and a minor Jurassic one with only very rare (one or two) older zircons; whilst the other half displays the same Mesozoic populations and in addition, a Late Proterozoic-Early Paleozoic population of variable importance (Fig. 5 \& 6). Interestingly, except in the Diahot Terrane which has no known basement, there is a close relationship between detrital zircon age patterns and the nature of underlying basement rocks (see Table 1) suggesting a local derivation for at least the older components. Therefore, an analysis of zircon populations in pre-Late Cretaceous 
terranes is necessary. The following section (5.1) is mainly based upon the data published in a recent paper by Adams et al. (2009b).

\section{Discussion}

\subsection{Possible local sources in New Caledonia's basement terranes}

Three pre-Late Cretaceous terranes have been recognised in New Caledonia, the Teremba, Central and Boghen terranes. These volcano-sedimentary terranes comprise three kinds of sedimentary rocks: i) Permian to mid-Cretaceous volcaniclastic turbidites usually termed greywacke (Teremba and Central); ii) minor Middle Triassic and Late Jurassic black shale and very rare sandstone (Teremba and Central); and, iii) mélange, in which undated (probably Jurassic-Early Cretaceous) black shale and sandstone are a minor component (Boghen Terrane).

About $80 \%$ of the volcaniclastic turbidites contain no datable detrital zircon because they mainly are derived from penecontemporaneous volcanic island-arc sources in which zircons are rare, or very small sized, unsuitable for U-Pb dating. When they contain zircons, they have the same age as the sediment, as established upon paleontological grounds (see Adams et al., 2009b). In contrast, the thin quartzose sandstone horizons associated with Middle Triassic and Late Jurassic black shale contain abundant detrital zircon. Both display a Mesozoic component which probably derive from the same volcanoplutonic-arc source; however, the most important populations are Paleozoic and late Proterozoic with three main components at 300-380, 400-430 and 430-680 Ma; and remarkably, no zircons in the 260300 Ma (Permian) interval (Fig. 7a \& 7b). It is noteworthy that proportions of the three aforementioned populations are similar in both Late Triassic and Late Jurassic sandstones; a feature which suggests that they originated from the same "continental" source. Sandstones in the Boghen Terrane display a similar well-developed Proterozoic component, but contrast in the paucity of early Paleozoic zircon, and a minor but still significant Permian population (Fig. 7c).

Owing to the comparatively large size of the late Proterozoic-early Paleozoic populations in the three basement terranes, it is difficult to determine from which ones the zircons derive. However, if the nature of the nearest basement rocks is considered (Table I), it appears that, when the underlying rocks are volcaniclastic turbidites, Late Cretaceous sandstones generally do not contain "older" zircons; in contrast, when the closest basement at least partly consists of sandstone, Proterozoic and Paleozoic zircons do then occur. Thus, it appears that the older zircon populations clearly derive from locally eroded pre-Late Cretaceous basement rocks. 
In addition, sandstones of the metamorphosed Diahot Terrane (north), for which there is no known basement, display the same features as those of the Formation à charbon (Fig. 6); therefore, they may have the same source and most probably accumulated upon an eroded basement of similar, if not the same, composition,.

\subsection{Possible sources outside New Caledonia}

Early Cretaceous volcanic rocks do not outcrop in New Caledonia and only a few occurrences of Early Cretaceous volcaniclastic turbidites have been recognised in the basement terranes, which do contain single zircon populations at ca. 130 and ca. $100 \mathrm{Ma}$ respectively (Cluzel et al., 2010). In contrast, a large amount of Early Cretaceous felsic volcanic rocks of this age appears in the Whitsunday Province of Eastern Australia (Ewart et al., 1992; Bryan et al., 1997) and such a provenance could be advocated. Long-range (> $1,000 \mathrm{~km}$ ) travel of sediments in deep sea fans is a common feature of passive and active margins as well (e.g., the Ganges deep sea fan, or the Nankaï Trough); however, under such circumstances sediment transits as mass flows and density currents, generating turbidites. The Late Cretaceous sandstone of New Caledonia were deposited in shallow water an environment that was already cut off from the continental influence by the Tasman Sea and probably the New Caledonia Basin. It therefore seems unlikely, that the Early Cretaceous sedimentary rocks are directly sourced from the Whitsunday Province, and local provenances are more likely. This is also supported by the endemic character of Late Cretaceous marine benthic faunas of New Caledonia, which suggest very few direct links with eastern Australia.

As mentioned above (sect. 4), the Early Cretaceous zircon population is composite when considering the bulk sample set; however, each individual sample contains one or two, and rarely three of these five Early Cretaceous populations only, thus precluding one single provenance. With only a few exceptions (Temala 1), all samples contain a prominent Albian population (ca. 100-110 Ma), which may have a local source in basement greywackes (Adams et al., 2009; Cluzel et al., 2010). However, Albian zircons alone represent about 30\% of the total population (table 2) and thus seem over-represented if we consider their very scarce occurrence in rocks of this age in New Caledonia. Therefore, an origin outside New Caledonia remains possible, and Eastern Australia being an unlikely source, a provenance from New Zealand and its submarine extensions, or Lord Howe Rise merits consideration.

The rifting along the eastern Australian margin probably initiated in Early Cretaceous time (ca. $130 \mathrm{Ma}$ ) and was initially associated with intraplate volcanism (Ewart et al., 1992; Bryan et al., 1997). Both rift-related extensional tectonics and magmatism migrated eastward 
from 130 to $85 \mathrm{Ma}$ and affected New Zealand and the Lord Howe Rise during the 110-90 Ma interval (McDougall \& Van Der Lingen, 1974; Tulloch et al., 2009; Collot et al., 2009; Higgins et al., in press) and New Caledonia at ca. 89-85 Ma (Cluzel et al., 2010). Thermal uplift, syntectonic sedimentation and erosion closely associated with the formation of graben and half-graben have been recognised in eastern Australia (Lister \& Etheridge, 1989), and in New Zealand (Tulloch \& Kimbrough, 1989; Shaerer, 1995; Laird \& Bradshaw, 2004). An unconformity between latest Cretaceous sediments and the underlying terranes appears on most seismic lines from the Lord Howe Rise. This indicated that at least parts of the Lord Howe Rise were subject to erosion whilst sediments accumulated in New Caledonia's graben, thus providing a plausible source for Cretaceous zircon populations; however, it is not clear whether sediments did cross into the future New Caledonia Basin or not.

\subsection{A comparison with New Zealand}

Although they are now $1800 \mathrm{~km}$ apart, New Caledonia and New Zealand share many geological features. Permian-Triassic and Jurassic macrofaunas share provincial characteristics (Campbell et al. 1985) and in both areas, Late Cretaceous-Paleogene sedimentary sequences (especially their Late Cretaceous syntectonic coal measures) are very similar (Tulloch \& Kimbrough, 1989; Shaerer, 1995). A precise reassembly of the many small continental fragments of northern Zealandia (Lord Hove Rise, Challenger Plateau, New Caledonia and North Island New Zealand), which are over considerable areas now submerged and draped by Cenozoic sedimentary rocks, remains uncertain. A suggested reconstruction is given in Adams et al. (2009, Fig. 6a). Therefore, in spite of some diachronism related to the marginal rifting process, they probably formed one single paleogeographic unit composed of a girdle of small islands located on uplifted blocks of the passive margin. With re-assembly of the many small continental fragments of the Australian margin (see Gaina et al., 1998a, b; Sutherland, 1999; Hall, 2002) (Fig. 8), New Zealand (both North and South Zealandia) would have been in a location where an Antarctic or Campbell Plateau provenance for Late Cretaceous sediments would be possible. Unlike New Caledonia, which only comprises Mesozoic volcanosedimentary terranes accumulated upon an "oceanic" basement, the south-easternmost part of New Zealand consists of a large fragment of Gondwanaland (early Paleozoic, Western Province) bounded to the east by the subduction-related Median Batholith and a mega-accretionary complex (the Eastern Province) (Bishop et al., 1985, Mortimer et al., 1999). In the Eastern Province, Early Cretaceous rocks form the youngest part of a long-lived (Permian to Cretaceous) accretionary 
complex at the active Zealonia margin. Sandstone-dominated sedimentary rocks of Aptian to Albian age (as young as $104 \mathrm{Ma}$ ) form a major Pahau Terrane, a Jurassic-Early Cretaceous sector of the Torlesse Composite Terrane (Bishop et al., 1985). It is extensive in northeast South Island and along the east coast of North Island. Recently, Early Cretaceous sedimentary rocks (maximum early Albian depositional age) have also been identified in the adjacent Waipapa Terrane to the west (otherwise mostly Jurassic-Triassic) in its northeasternmost extremity in Coromandel Peninsula and Great Barrier Island, North Island. A small allochthonous section of the accretionary complex (East Cape Allochthon) is also Albian in age.

The accretionary complex waned considerably in late Aptian-Albian time (c. 110-114 $\mathrm{Ma}$ ), and throughout northeastern South Island and eastern North Island the Pahau Terrane is covered by late Early Cretaceous (Albian) to Late Cretaceous cover successions, mainly shallower-water marine sedimentary rocks. In Northland (northernmost North Island) these cover successions are far more limited and allochthonous (mostly Late Cretaceous-Cenozoic in the Northland Allochthon) or form a discrete terrane (late Early Cretaceous, Mt Camel Terrane). The Northland Allochthon was emplaced upon Murihiku Terrane (JurassicTriassic) and Waipapa Terrane (Jurassic basement), but the relationship of the Mt Camel Terrane to basement is uncertain.

With few exceptions the detrital zircon age patterns in sandstones of the Early Cretaceous accretionary complex (both Pahau and Waipapa Terranes) record the enduring presence of a major Early Triassic-Late Permian component (240-260 Ma) and, in the Pahau Terrane at least, substantial minor proportions of early Paleozoic-Precambrian zircons. The primary sources for these are probably in the New England Orogen, and its older hinterland, in Queensland and New South Wales, eastern Australia (Adams et al. 2007, 2009a). There is a substantial, but minor group, increasing from north to south, of late Early Cretaceous (mainly 130 to $114 \mathrm{Ma}$ ) zircon ages, which record the synchronous rise of magmatism within the Median Batholith, which is situated between the Eastern Province and the Gondwana continental foreland of the Western Province. In detail, the age subcomponents within this broad late Early Cretaceous age group, c. 112, 116, 120, and 125 Ma, resemble those found in New Caledonia.

The detrital zircon age patterns in the Cretaceous cover successions that overlie the Pahau Terrane mostly inherit those of the nearby basement rocks, thus continuing to acquire major proportions of reworked Early Triassic-Late Permian zircons. Again, a late Early Cretaceous, 130 to $100 \mathrm{Ma}$, group is minor, but important, with subcomponents c. 104, 108, 116, 120, 
125 Ma. Similar Early Cretaceous zircon age components are found within the Northland Allochthon and Mt Camel Terrane successions of Albian age, but in the latter at least, there is evidence that contemporaneous acidic volcanism could have provided a local source. In these northern mid-Cretaceous cover successions there is some evidence that minor, JurassicTriassic reworked zircons are derived from the local Murihiku Terrane (Adams et al., submitted).

In both the eastern and northern New Zealand regions described above, the Late Cretaceous sandstones (examples studied are Coniacian to Campanian) in the cover successions show a detrital zircon age pattern without the Albian zircon components that are characteristic of their mid-Cretaceous (Albian-early Cenomanian) counterparts. For the most part, they contain only pre-Jurassic zircons with a pattern that resembles those in the Pahau Terrane (in eastern New Zealand) and the Murihiku Terrane (in northern New Zealand). This suggests that some process occurred at c. $100 \mathrm{Ma}$, to quickly bury or block any midCretaceous (Albian-early Cenomanian) zircon sources in their more localised occurrences, yet allowed an eroding, extensive Eastern Province hinterland to prevail for another 30 million years (Adams et al., submitted). It may be suggested that, as elsewhere along the former Australian margin, the diachronous eastward propagating development of horst and graben structure (Cluzel et al., 2010) provoked the extensive erosion of uplifted basement terranes; whilst subsiding parts were buried and protected from erosion, and thus could not provide detrital zircon to syntectonic basins.

Therefore, the contrasting detrital zircon patterns of Late Cretaceous cover series in both New Zealand and New Caledonia, and the distance they would have travelled in such a case (see 6.2 above), preclude a New Zealand provenance for the zircon populations found in Late Cretaceous sandstones of New Caledonia.

\section{Conclusion}

The Late Cretaceous sandstones that form the uncomfortable cover of the Mesozoic basement terranes of New Caledonia display detrital zircon age patterns that suggest a local derivation for the minor Precambrian to early Mesozoic age components. In contrast, the provenance of Cretaceous zircons, which represent about $80 \%$ of the bulk content, is somewhat uncertain. Cretaceous zircons may derive from outside New Caledonia for example possibly from the Lord Howe Rise, which might contain the northern extension of the Median Batholith as well as a possible rift-related volcanic province of mid-Cretaceous age. However, this interpretation infers that mid to Late Cretaceous grabens, precursors of 
the New Caledonia Basin, were not a barrier for sedimentary transit in Coniacian-Santonian time. Alternatively, Cretaceous zircons may also have a local provenance and come from previously undiscovered Cretaceous volcaniclastic turbidites, which would have been almost completely eroded before the Late Cretaceous transgression. This view is supported by Cretaceous detrital zircon populations, which differ from place to place and are unlikely to have just a single remote origin. It is worth noting that a similar source persisted during the Coniacian-Campanian period, during which detrital zircon populations display the same components. In any case, at variance with previous interpretations, an Australian provenance cannot be advocated, and New Caledonia, although still part of the Australian Continent until the Campanian, would have been already disconnected from the main continental landmass.

\section{Acknowledgements}

The authors acknowledge the useful review of the first version of this article by Dr C.J. Allen and an anonymous reviewer. 


\section{References}

Adams CJ, Campbell HJ, Griffin, WR 2007. Provenance Comparisons of Permian to Jurassic Tectonostratigraphic Terranes in New Zealand: Perspectives from detrital zircon age patterns. Geological Magazine, 144: 701-729.

Adams CJ, Mortimer, N, Campbell, HJ, Griffin W.L. 2009a. Age and isotopic characterisation of metasedimentary rocks from the Torlesse Supergroup and Waipapa Group in the central North Island, New Zealand. New Zealand Journal of Geology and Geophysics 52: $149-170$.

Adams C.J., Cluzel D., and Griffin W.L. 2009b. Detrital zircon ages and provenance of sedimentary rocks in basement Mesozoic terranes of New Caledonia. Australian Journal of Earth Sciences 56, 1023-1047. doi: 10.1080/08120090903246162

Adams C.J., Mortimer N., Campbell H.J., Griffin W.L. (submitted). The mid-Cretaceous transition from basement to cover sedimentary rocks in New Zealand: evidence from detrital zircon age patterns. Submitted to New Zealand Journal of Geology and Geophysics

Aitchison J.C., Clarke G.L., Cluzel D., Meffre S., 1995a. Eocene arc-continent collision in New Caledonia and implications for regional southwest Pacific tectonic evolution, Geology, 23, 161-164

Aitchison, J.C., Meffre, S., Cluzel, D., 1995b. Cretaceous/Tertiary Radiolarians from New Caledonia. Geological Society of New Zealand, Miscellaneous Publication 81A, p. 70.

Aitchison J.C., Ireland T.R., Clarke G.L., Cluzel D., Davis A.M. and Meffre S., 1998. Regional implications of U/Pb SHRIMP age constraints on the tectonic evolution of New Caledonia, Tectonophysics 299, 333-343.

Alexander, A. M., Nicholson, K. N., Simonetti, A., Maurizot, P., and Cluzel, D., 2010. Dating rhyolite flows in the Noumea basin, New Caledonia, in order to constrain the breakup of the eastern Gondwana margin. GSA 44th Annual Meeting, Branson, Mi, USA. April 1113, 2010. Abstracts with Programs V. 42, $\mathrm{n}^{\circ} 2$.

Aronson J.L., and Tilton G.R., 1971. Probable precambrian detrital zircons in New Caledonia and Southwest Pacific continental structure. Geol. Soc Amer. Bull., 82, 12, 34493456.

Baker, J., Peate, D., Waight, T. and Meyzen, C., 2004. Pb isotopic analysis of standards and samples using a $\mathrm{Pb}-207-\mathrm{Pb}-204$ double spike and thallium to correct for mass bias with a double-focusing MC-ICP-MS. Chemical Geology, 211, 275-303. 
Bishop, D. G., Bradshaw, J. D. \& Landis, C. A. 1985. Provisional terrane map of South Island, New Zealand. In Howell, D.G. (ed) Tectonostratigraphic Terranes, Circum - Pacific Council for Energy and Mineral Resources Earth Science Series No. 1, Houston, Texas, 515521.

Black L. P., Gulson B. L. 1978. The age of the Mud tank Carbonatite, Strangways Range, Northern Territory. BMR Journal of Australian Geology and Geophysics 3, 227-232.

Black, L. P., Kamos, L., Allen, C.M., Aleinikoff, J.N., Davis, D.W., Korsch, R.J., Foudoulis, C., 2003, TEMORA 1: a new zircon standard for Phanerozoic U-Pb geochronology. Chemical Geology 200, 155- 170.

Black, L.P., Kamo, S.L., Allen, C.M., Davis, D.W., Aleninikoff, J.N., Valley, J.W., Mundil, R., Campbell, I.H., Korsch, R.J., Williams, I.S., Foudoulis, C., 2004, Improved $206 \mathrm{~Pb} / 238 \mathrm{U}$ microprobe geochronology by the monitoring of a trace-element related matrix effect; SHRIMP, ID-TIMS, ELA-ICP-MS, and oxygen isotope documentation for a series of zircon standards. Chemical Geology 205, 115-140.

Brothers, R.N., Blake, M.C., 1972. Tertiary plate tectonics and high-pressure metamorphism in New Caledonia. Tectonophysics, 17, 359-391.

Bryan S.E., A.E. Constantine, C.J. Stephens, A. Ewart, R.W. Schon, J. Parianos, 1997. Early Cretaceous volcano-sedimentary successions along the eastern Australian continental margin: Implications for the break-up of eastern Gondwana. Earth and Planetary Science Letters 153, 85-102.

Burns R.E., Andrews J.E., et al., 1973, Initial Reports of the Deep Sea Drilling Project, 21, Washington, D.C., U.S. Government Printing Office.

Campbell, H.J., Grant-Mackie, J.A., and Paris, J.P. 1995. Geology of the Moindou Téremba area, New Caledonia : statigraphy and structure of the Téremba Group, (PermianLower Triassic) and Baie de St Vincent Group (Upper Triassic- Lower Triassic). Géologie de la France, BRGM. 1, 19-36.

Carroué J. P., 1972. Carte et notice explicative de la carte géologique de la NouvelleCalédonie à l'échelle du 1/50000: feuille Pouembout. Bureau de Recherches Géologiques et Minières, Orléans France.

Chang, Z., Vervoort, J. D., McClelland, W. C., and Knaack, C., 2006, U-Pb dating of zircon by LA-ICP-MS: Geochemistry, Geophysics, Geosystems, v. 7.

Clarke, G., Aitchison, J.C., Cluzel, D., 1997. Eclogites and blueschists of the Pam Peninsula, NE New Caledonia : a reappraisal. Jour Metam. Petrology 38, 7, 843-876. 
Cluzel D., Aitchison J.C., Picard C., 2001. Tectonic accretion and underplating of mafic terranes in the Late Eocene intraoceanic fore-arc of New Caledonia (Southwest Pacific). Geodynamic implications. Tectonophysics 340, 1-2, 23-60.

Cluzel D., and Meffre S., 2002. L'unité de la Boghen (Nouvelle-Calédonie, Pacifique sud-ouest): un complexe d'accrétion jurassique. Données radiochronologiques préliminaires U-Pb sur les zircons détritiques. C.R.Géosciences. 334, 867-874.

Cluzel D., Adams C.J.A., Meffre S., Campbell H., and Maurizot P. 2010. Discovery of Early Cretaceous rocks in New Caledonia: New geochemical and U-Pb zircon age constraints on the transition from subduction to marginal break-up in the Southwest Pacific. The Journal of Geology 118, 4, 381-397.

Collignon M., 1977. Ammonites néocrétacées de la Nouvelle-Calédonie. Bull. B.R.G.M., Fr., sect. 4, 1, 7-36.

Collot J., Herzer R.H., Lafoy Y., and Geli L., 2009. Mesozoic history of the FairwayAotea Basin: Implications for the early stages of Gondwana fragmentation. Geochemistry, Geophysics, Geosystems 10, 12, Q12019, doi:10.1029/2009GC002612

Compston, W., 1999, Geological age by instrumental analysis: the 29th Hallimond Lecture. Mineralogical Magazine 63, 297-311.

Crié L., 1888. Beiträge zur Kenntniss der fossilen Flora einiger Inseln des Südpacifischen und Indischen Ocean. Paleontologische Abhandlungen, Jena. Verlag von Gustav Fischer, S. 77. Taf. IX-XVIII.

Espirat J.J. 1963. Etude géologique de régions de la Nouvelle-Calédonie septentrionale (extrémité nord et versant est). Thèse doct. Etat, 217 p., 27 pl h.t., 2 cartes h.t.

Ewart A., R.W. Schön, B.W. Chappell, 1992. The Cretaceous volcanic-plutonic province of the central Queensland Australia coast - a rift related “'calc-alkaline”’ province, Trans. R. Soc. Edinburgh Earth Sci. 83, 327-345.

Fitzherbert J.A., Clarke G.L., and Powell R., 2005. Preferential retrogression of high-P metasediments and the preservation of blueschist to eclogite facies metabasite during exhumation, Diahot terrane, NE New Caledonia. Lithos 83, 67-96.

Freinex S., 1980. Bivalves néocrétacés de Nouvelle-Calédonie. Signification biogéographique, biostratigraphique, paléoécologique. Annales de Paléontologie (invertébrés) 66, 2, 67-134.

Freinex S., 1981. Faunes de bivalves du Sénonien de Nouvelle-Calédonie. Analyses paléobiogéographique, biostratigraphique, paléoécologique. Annales de Paléontologie (invertébrés) 67, 1, 13-32. 
Fryer, B.J., Jackson, S.E., Longerich, H.P., 1993, The Application of Laser Ablation Microprobe-Inductively Coupled Plasma-Mass Spectrometry (Lam-Icp-Ms) to in situ (U)-Pb Geochronology. Chemical Geology 109, 1-8.

Gaina C., Roest W.R., Müller R. D., and Symonds P., 1998a. The Opening of the Tasman Sea: A Gravity Anomaly Animation. Earth Interactions, 2, 1-23.

Gaina, C., Müller R.D., Royer J.-Y., Stock J., Hardebeck J., and Symonds P., 1998b. The tectonic evolution of the Tasman Sea: A tectonic puzzle with thirteen pieces. J. Geophys. Res., 103, (B6), 12,413-12,433.

Grant-Mackie, J. A., Paris, J. P. Freneix, S., \& Campbell, J. D. 1977. Advances in correlation of Mesozoic sequences in New Zealand and New Caledonia. 25th International Geological Congress, Abstracts, 1, 268-269.

Hall R. 2002. Cenozoic geological and plate tectonic evolution of SE Asia and the SW Pacific: computer-based reconstructions, model and animations. Journal of Asian Earth Sciences 20, 4, 353-431. doi:10.1016/S1367-9120(01)00069-4.

Harley, S.L. and Kelly, N.M., 2007. Zircon: Tiny but timely. Elements, 3(1): 13-18.

Higgins, K., Hashimoto, T., Fraser, G., Rollet, N. and Colwell, J., in press. Ion microprobe (SHRIMP) U-Pb dating of Upper Cretaceous volcanics from the northern Lord Howe Rise, Tasman Sea. Australian Journal of Earth Sciences.

Jackson, S.E., Pearson, N.J., Griffin, W.L., Belousova, E.A., 2004, The application of laser ablation-inductively coupled plasma-mass spectrometry to in situ U-Pb zircon geochronology. Chemical Geology 211, 47-69.

Kosler J., and Sylvester P.J., 2003. Present trends and the future of zircon in geochronology; laser ablation ICPMS. Reviews in Mineralogy and Geochemistry 53, 243275.

Kosler, J., 2001, Laser-ablation ICPMS study of metamorphic minerals and processes. In: Sylvester P. J. ed. Laser-ablation-ICPMS in the earth sciences; principles and applications Mineralogical Association of Canada Short Course Handbook 29, 185-202.

Laird M.G. and Bradshaw J.D., 2004. The break-up of a long-term relationship: the Cretaceous separation of New Zealand from Gondwana. Gondwana Research 7, 1, 273-286.

Lister G.S., and Etheridge M.A., 1989. Detachment models for uplift and volcanism in the Eastern Highlands, and their implication to the origin of passive margin mountains, in: R.W. Johnson, S.R. Taylor Eds., Intraplate Volcanism in Eastern Australia and New Zealand, Cambridge University Press, 297-313. 
Ludwig, K.R., 2003. User's Manual for Isoplot 3.00 a Geochronological Toolkit for Microsoft Excel.

Maurizot, P., Eberlé, J.M., Habault, C., Tessarolo, C., 1989. Carte géol. Territoires d'Outre-Mer, Nouvelle-Calédonie (1/50000), feuille Pam-Ouégoa, 2e édition, B.R.G.M., Notice explicative par Maurizot P., Eberlé J.M., Habault C., et Tessarolo C., 81p.

McDougall, I., and Van Der Lingen, G. J. 1974. Age of the rhyolites of the Lord Howe Rise and the evolution of the Southwest Pacific Ocean. Earth and Planetary Science Letters 21, 117-126.

Meffre, S., Large, R. R., Scott, R., Woodhead, J., Chang, Z., Gilbert, S. E., Danyushevsky, L. V., Maslennikov, V., and Hergt, J. M., 2008, Age and pyrite Pb-isotopic composition of the giant Sukhoi Log sediment-hosted gold deposit, Russia: Geochimica et Cosmochimica Acta, 72, 2377-2391.

Moore, P. R. \& New Zealand Geological Survey 1988. Stratigraphy, composition and environment of deposition of the Whangai Formation and associated Late CretaceousPaleocene rocks, eastern North Island, New Zealand / by P.R. Moore New Zealand Geological Survey, Lower Hutt, N.Z. 82p.

Mortimer N. 2004. New Zealand's Geological Foundations. Gondwana Research, 7, Issue 1, 261-272.

Mortimer, N., Tulloch, A. J., Gans, P., Calvert \& Walker, N. 1999. Geology and thermochronometry of the east edge of the Median Tectonic Batholith (Median Tectonic Zone): a new perspective on Permian to Cretaceous crustal growth of New Zealand. Island Arc 8, 404-425.

Muir R.J., Ireland T.R., Weaver S.D., Bradshaw J.D., Waight T.E., Jongens R., Eby G.N. 1997. SHRIMP U-Pb geochronology of Cretaceous magmatism in northwest NelsonWestland, South Island, New Zealand New Zealand Journal of Geology and Geophysics, 40, 453-463. doi: 0028-8306/97/4004-0453

Paris, J.P., 1981. Géologie de la Nouvelle-Calédonie. Un essai de synthèse, Mem. BRGM, 113, 278 p.

Paton,C., Woodhead, J D., Hellstrom, J C. . Hergt, JM, Greig,A and Maas, R. 2010 Improved laser ablation U-Pb zircon geochronology through robust down-hole fractionation correction. Geochemistry, Geophysics, Geosystems11, 1525-2027

Picard, M., 1995. Ouverture de bassins marginaux dans le Pacifique sud-ouest. Paléovolcanisme et reconstitution des environnements géodynamiques. Extrémité nord de la Nouvelle-Calédonie, Unpubl. MSc thesis, Univ. Grenoble, 124 p. 
Shaerer J.C., 1995. Tectonic controls on styles of sediment accumulation in the Late Cretaceous Morley Coal Measures of Ohai Coalfield, New Zealand. Cretaceous Research 16, 367-384.

Sutherland R. 1999. Basement geology and tectonic development of the greater New Zealand region: an interpretation from regional magnetic data. Tectonophysics 308, 3, 341362. doi:10.1016/S0040-1951(99)00108-0.

Tulloch A. J., Ramezani J., Mortimer N., Mortensen J., van den Bogaard P., and Maas R. 2009. Cretaceous felsic volcanism in New Zealand and Lord Howe Rise (Zealandia) as a precursor to final Gondwana break-up. Geological Society, London, Special Publications; 321, 89-118; DOI: 10.1144/SP321.5

Tulloch, A. J., and Kimbrough D. L., 1989. The Paparoa metamorphic core complex, New Zealand: Cretaceous extension associated with fragmentation of the Pacific margin of Gondwana, Tectonics, 8(6), 1217-1234.

Van de Beuque 1999. Evolution géologique du domaine péri-calédonien -sud-ouest Pacifique). Unpubl. PhD thesis Université de Bretagne Occidentale, Brest, France, 269 pp. Wiedenbeck, M., Alle, P., Corfu, F., Griffin W.L., Meier, M., Oberli, F., Vonquadt A., Roddick, J.C., Speigel W., 1995, 3 Natural Zircon Standards for U-Th-Pb, Lu-Hf, TraceElement and REE Analyses. Geostandards Newsletter 19, 1-23.

Wilckens O. 1925. Stratigraphie und bau von Neu Caledonien. Geol. Rdsch. Leipzig, 16, 2, 128-142.

Zeiller R., 1889. Note sur quelques empreintes végétales des couches de charbon de la Nouvelle-Calédonie. Bull. Soc. Géol. Fr., 3e série, 17, 443-446. 
Table 1: New Caledonia Late Cretaceous sandstone sample data.

\begin{tabular}{|c|c|c|c|c|c|c|c|c|c|c|}
\hline sample & $\begin{array}{l}\text { Loc. on } \\
\text { Fig } 1\end{array}$ & $\begin{array}{l}\text { Location } \\
\text { name }\end{array}$ & coordinates & terrane & lithology & assumed age & $\begin{array}{l}\text { underlying } \\
\text { terrane }\end{array}$ & $\begin{array}{l}\text { younguest } \\
\text { zircon }\end{array}$ & $\begin{array}{c}\begin{array}{c}\text { younguest } \\
\text { zircon } \\
\text { population }\end{array} \\
\end{array}$ & older populations \\
\hline NOU 121 & 1 & Boulari & $\begin{array}{c}22^{\circ} 13^{\prime} 50^{\prime \prime S} \\
166^{\circ} 31^{\prime} 20^{\prime \prime E}\end{array}$ & $\begin{array}{c}\text { Fm à } \\
\text { charbon }\end{array}$ & $\begin{array}{l}\text { feldspathic } \\
\text { sandstone }\end{array}$ & $\begin{array}{c}\text { Coniacian- } \\
\text { Santonian }\end{array}$ & $\begin{array}{c}\text { Teremba } \\
\text { (volcaniclastic) }\end{array}$ & $96 \pm 2 \mathrm{Ma}$ & $\begin{array}{c}101.7 \pm 1.2 \mathrm{Ma} \\
(\mathrm{n}=25)\end{array}$ & $\begin{array}{c}115,135,188 \\
211 \mathrm{Ma}\end{array}$ \\
\hline NCAL 24 & 2 & $\begin{array}{l}\text { near Koh } \\
\text { village }\end{array}$ & $\begin{array}{c}21^{\circ} 33^{\prime} 48^{\prime \prime S} \\
165^{\circ} 49^{\prime} 57^{\prime \prime E}\end{array}$ & $\begin{array}{c}\text { Fm à } \\
\text { charbon }\end{array}$ & sandstone & $\begin{array}{c}\text { Santonian- } \\
\text { Campanian ? }\end{array}$ & $\begin{array}{c}\text { Central } \\
\text { (volcaniclastic) }\end{array}$ & $80 \pm 2 \mathrm{Ma}$ & $\begin{array}{c}85 \pm 2 \mathrm{Ma} \\
(\mathrm{n}=5)\end{array}$ & $\begin{array}{c}130-95 \text { Ма 200- } \\
160 \mathrm{Ma}\end{array}$ \\
\hline BOU 12 & 3 & Boghen Pass & $\begin{array}{c}21^{\circ} 37^{\prime} 22^{\prime \prime S} \\
165^{\circ} 38^{\prime} 02^{\prime \prime E}\end{array}$ & $\begin{array}{c}\text { Fm à } \\
\text { charbon }\end{array}$ & sandstone & $\begin{array}{l}\text { Coniacian- } \\
\text { Santonian }\end{array}$ & Teremba & $89 \pm 2 \mathrm{Ma}$ & $\begin{array}{c}89 \pm 4 \mathrm{Ma} \\
(\mathrm{n}=3)\end{array}$ & $\begin{array}{c}\text { 101, 126, 192, } 239 \\
\text { Ма }\end{array}$ \\
\hline BOU 13 & 3 & Boghen Pass & $\begin{array}{c}21^{\circ} 37^{\prime} 22^{\prime S} \\
165^{\circ} 38^{\prime} 02^{\prime \prime E}\end{array}$ & $\begin{array}{c}\text { Fm à } \\
\text { charbon }\end{array}$ & siltstone & Campanian ? & Teremba & $76 \pm 1 \mathrm{Ma}$ & $\begin{array}{c}78 \pm 3 \mathrm{Ma} \\
(\mathrm{n}=6)\end{array}$ & $\begin{array}{c}\text { 100, 124, 136, 184, } \\
212 \mathrm{Ma}\end{array}$ \\
\hline FTN 1 & 4 & $\begin{array}{l}\text { Faténaoué } \\
\text { riv. }\end{array}$ & $\begin{array}{l}20^{\circ} 52^{\prime} 14^{\prime \prime} \mathrm{S} \\
164^{\circ} 45^{\prime} 26^{\prime \prime E}\end{array}$ & $\begin{array}{c}\text { Fm à } \\
\text { charbon }\end{array}$ & sandstone & $\begin{array}{l}\text { Coniacian- } \\
\text { Santonian }\end{array}$ & $\begin{array}{c}\text { Boghen } \\
\text { (sandstone) }\end{array}$ & $85 \pm 2 \mathrm{Ma}$ & $\begin{array}{c}88.2 \pm 1.5 \mathrm{Ma} \\
\quad(\mathrm{n}=10)\end{array}$ & $\begin{array}{c}102.6 \pm 1.4 \mathrm{Ma} \\
156,290,500-700\end{array}$ \\
\hline CONG 1 & 5 & Congo riv. & $\begin{array}{l}20^{\circ} 54 ' 64^{\prime \prime} \mathrm{S} \\
164^{\circ} 46^{\prime} 49^{\prime \prime E}\end{array}$ & $\begin{array}{c}\text { Fm à } \\
\text { charbon }\end{array}$ & sandstone & $\begin{array}{l}\text { Coniacian- } \\
\text { Santonian }\end{array}$ & Boghen (schist) & $86 \pm 4 \mathrm{Ma}$ & $\begin{array}{c}103.1 \pm 2.4 \mathrm{Ma} \\
(\mathrm{n}=11)\end{array}$ & $\begin{array}{c}\text { 310-405, 540-625 } \\
\text { 850-1100 Ма }\end{array}$ \\
\hline TML 1 & 6 & Temala riv. & $\begin{array}{l}20^{\circ} 49^{\prime} 13^{\prime \prime} \mathrm{S} \\
164^{\circ} 41^{\prime} 51^{\prime \prime E}\end{array}$ & $\begin{array}{c}\text { Fm à } \\
\text { charbon }\end{array}$ & sandstone & Santonian? & $\begin{array}{c}\text { Boghen } \\
\text { (sandstone) }\end{array}$ & $84 \pm 3 \mathrm{Ma}$ & $\begin{array}{c}84.6 \pm 2 \mathrm{Ma} \\
(n=3)\end{array}$ & $\begin{array}{c}141,197,270,375 \\
400-700,800,900 \\
1000\end{array}$ \\
\hline PAIMB 2 & 7 & $\begin{array}{c}\text { Témélin } \\
\text { (Paimboas) }\end{array}$ & $\begin{array}{c}20^{\circ} 30^{\prime} 40^{\prime \prime S} \\
164^{\circ} 34^{\prime} 24^{\prime \prime E}\end{array}$ & Diahot? & $\begin{array}{c}\text { meta- } \\
\text { sandstone }\end{array}$ & $\begin{array}{c}\text { Late } \\
\text { Cretaceous? } \\
\text { (Tertiary HP- } \\
\text { LT complex) }\end{array}$ & Central ? & $86 \pm 2 \mathrm{Ma}$ & $\begin{array}{c}93 \pm 2 \mathrm{Ma} \\
(\mathrm{n}=11)\end{array}$ & $\begin{array}{c}115 \pm 4 \mathrm{Ma} \\
180 \mathrm{Ma}\end{array}$ \\
\hline PAIMB 1 & 7 & $\begin{array}{c}\text { Témélin } \\
\text { (Paimboas) }\end{array}$ & $\begin{array}{c}20^{\circ} 32^{\prime} 06^{\prime \prime S} \\
164^{\circ} 33^{\prime} 40^{\prime \prime E}\end{array}$ & Diahot? & $\begin{array}{c}\text { meta- } \\
\text { conglomerate }\end{array}$ & $\begin{array}{c}\text { Late } \\
\text { Cretaceous ? } \\
\text { (Tertiary HP- } \\
\text { LT complex) }\end{array}$ & Central ? & $85 \pm 6 \mathrm{Ma}$ & $\begin{array}{c}99 \pm 3 \mathrm{Ma} \\
(\mathrm{n}=5)\end{array}$ & $\begin{array}{c}159 \pm 5 \\
250-212 \\
850-650\end{array}$ \\
\hline PAIMB 4 & 8 & $\begin{array}{c}\text { south of } \\
\text { Paimboas }\end{array}$ & $\begin{array}{c}20^{\circ} 32^{\prime} 47^{\prime \prime S} \\
164^{\circ} 30^{\prime} 40^{\prime \prime E}\end{array}$ & Diahot & sandstone & $\begin{array}{c}\text { Late } \\
\text { Cretaceous }\end{array}$ & unknown & $92 \pm 5 \mathrm{Ma}$ & $\begin{array}{c}103.0 \pm 2.2 \mathrm{Ma} \\
(\mathrm{n}=24)\end{array}$ & $\begin{array}{c}172 \\
942,614\end{array}$ \\
\hline OUGN 1 & 9 & $\begin{array}{l}\text { Marais } \\
\text { d'Ougne }\end{array}$ & $\begin{array}{l}20^{\circ} 19^{\prime} 47^{\prime} \mathrm{S} \\
164^{\circ} 17^{\prime} 57^{\prime \prime E}\end{array}$ & Diahot & $\begin{array}{l}\text { disrupted } \\
\text { sandstone }\end{array}$ & $\begin{array}{c}\text { Late } \\
\text { Cretaceous? } \\
\text { (Tertiary HP- } \\
\text { LT complex) }\end{array}$ & unknown & $97 \pm 11 \mathrm{Ma}$ & $\begin{array}{c}102.0 \pm 3.7 \mathrm{Ma} \\
(\mathrm{n}=5)\end{array}$ & $\begin{array}{c}113,120,135,300 \\
340,405,485,570 \\
770\end{array}$ \\
\hline
\end{tabular}


Table 2: a summary of the main detrital zircon populations from the Late Cretaceous Formation à charbon.

\begin{tabular}{|c|c|c|c|}
\hline & $\begin{array}{c}\text { Number of } \\
\text { zircon grains }\end{array}$ & Age Ma & $\begin{array}{c}\text { total } \\
\text { fraction } \%\end{array}$ \\
\hline \multirow{8}{*}{ Cretaceous } & \multirow{8}{*}{$\mathrm{n}=322$} & 78 & \multirow{8}{*}{67.0} \\
\hline & & 88 & \\
\hline & & 94 & \\
\hline & & 101 & \\
\hline & & 104 & \\
\hline & & 115 & \\
\hline & & 119 & \\
\hline & & 130 & \\
\hline \multirow{4}{*}{ Jurassic } & \multirow{4}{*}{$\mathrm{n}=26$} & 157 & \multirow{4}{*}{5.4} \\
\hline & & 167 & \\
\hline & & 181 & \\
\hline & & 186 & \\
\hline \multirow{4}{*}{ Triassic } & \multirow{4}{*}{$\mathrm{n}=18$} & 200 & \multirow{4}{*}{3.7} \\
\hline & & 210 & \\
\hline & & 221 & \\
\hline & & 246 & \\
\hline Paleozoic & $\mathrm{n}=37$ & & 7.7 \\
\hline Neoproterozoic & $\mathrm{n}=54$ & & 12.8 \\
\hline Mesoproterozoic & $\mathrm{n}=13$ & & 2.7 \\
\hline
\end{tabular}




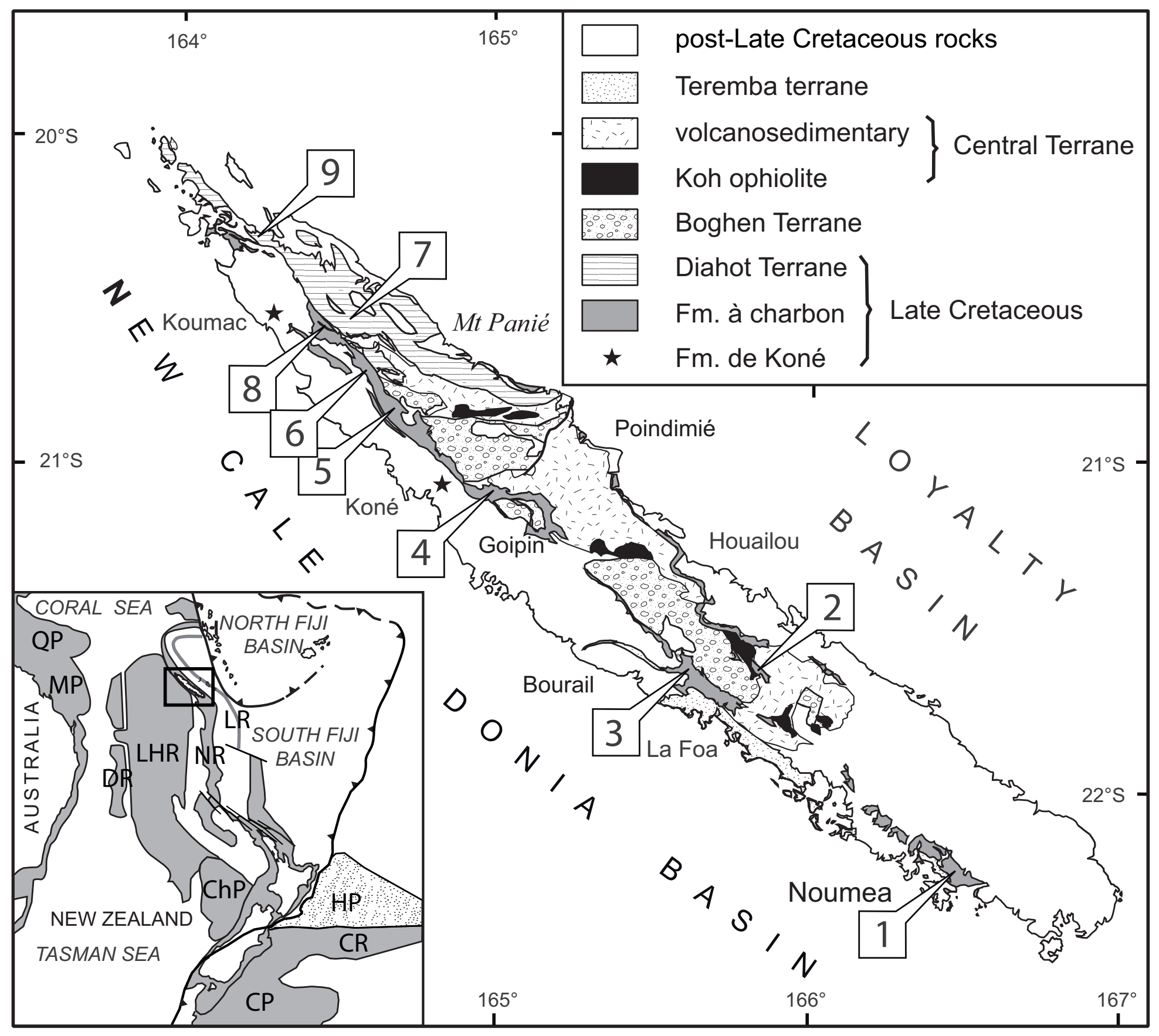

Figure 1: Geological map of New Caledonia basement terranes, Late Cretaceous rocks and U-Pb geochronology sampling localities 


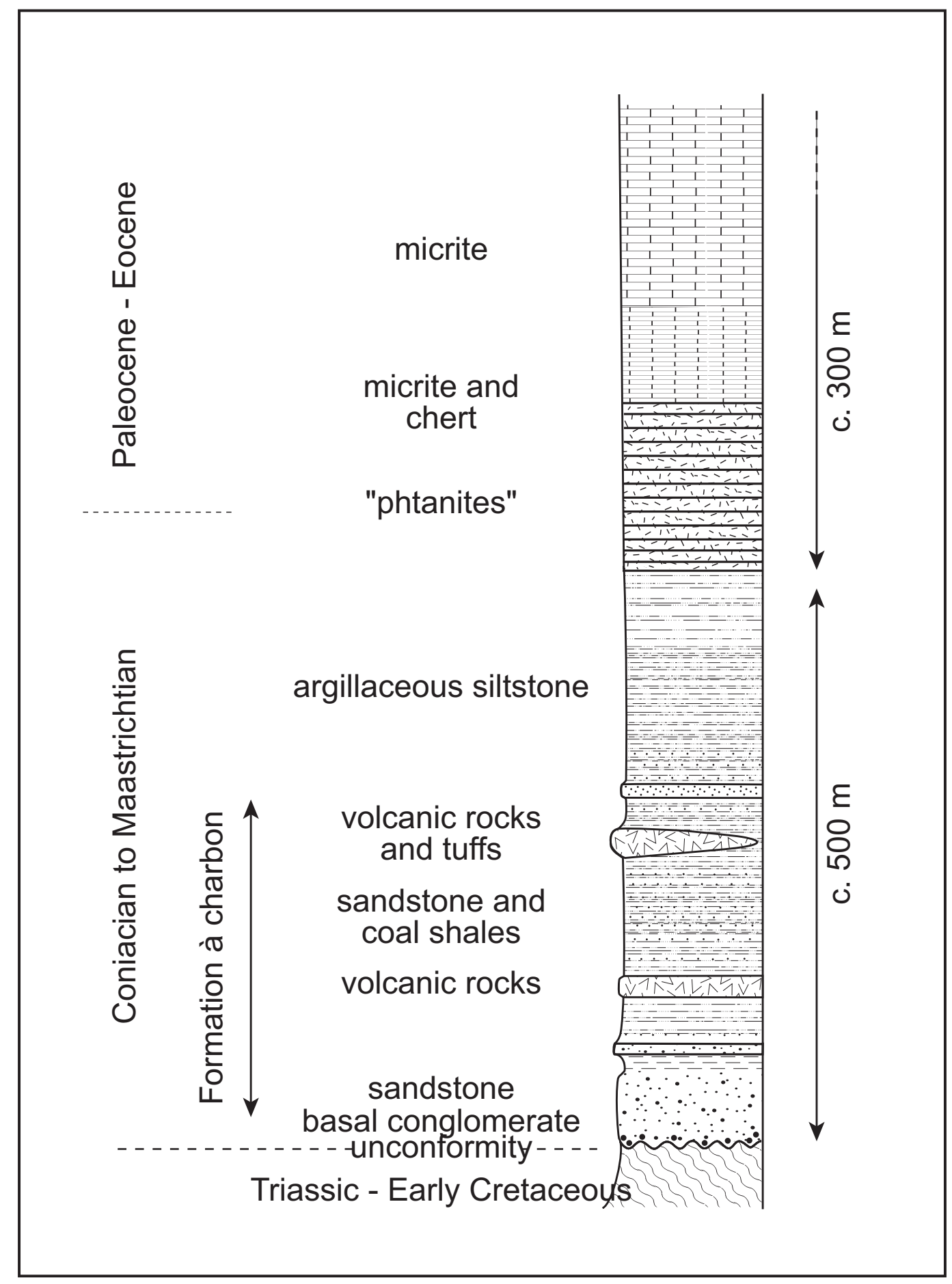

Figure 2: Late Cretaceous to Eocene sedimentary autochthonous sequence of New Caledonia 


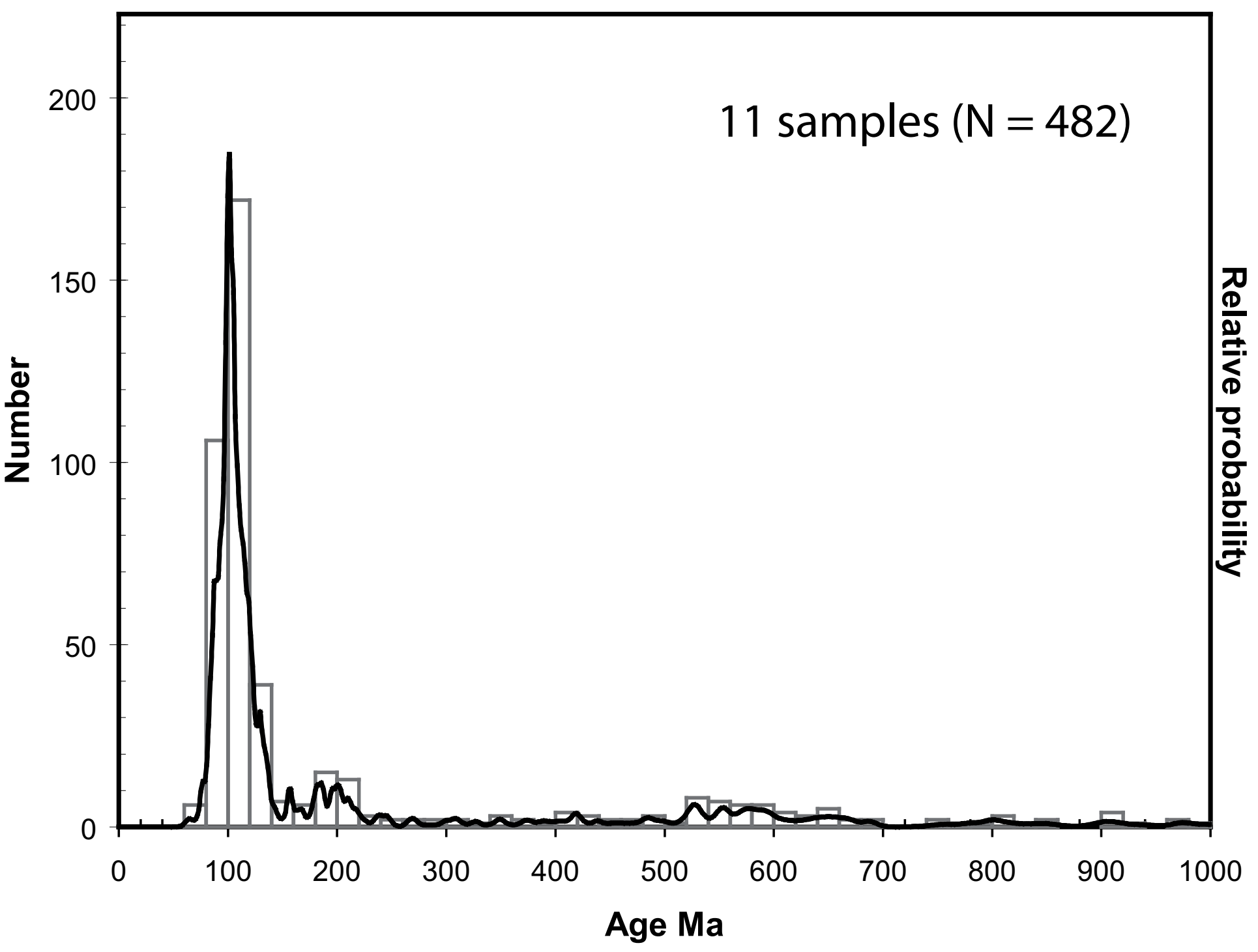

Figure 3: probability age diagram of detrital zircons of the Formation à charbon sandstone (all samples) 


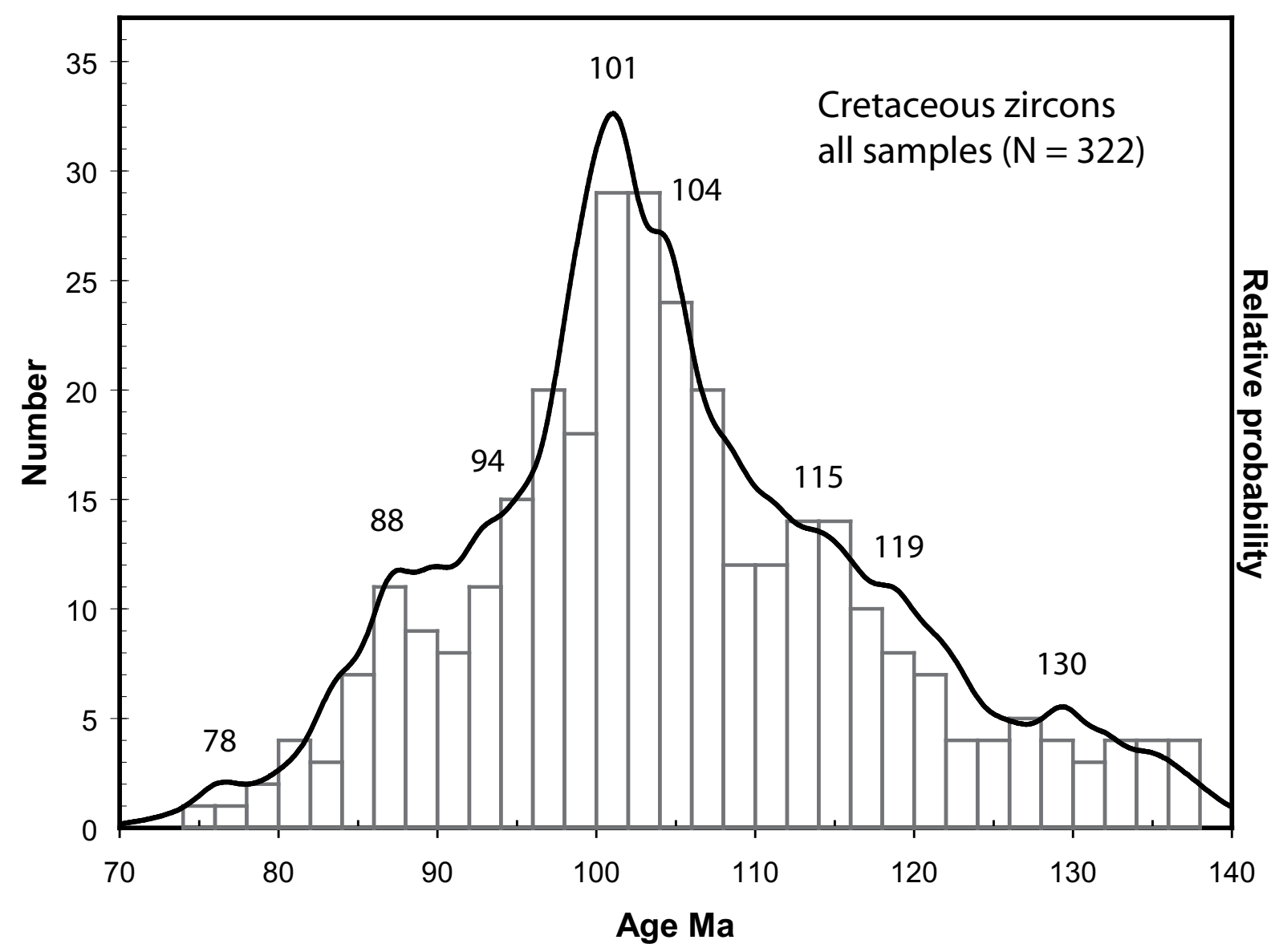

Figure 4: a detailed view of the composite Cretaceous zircon population 

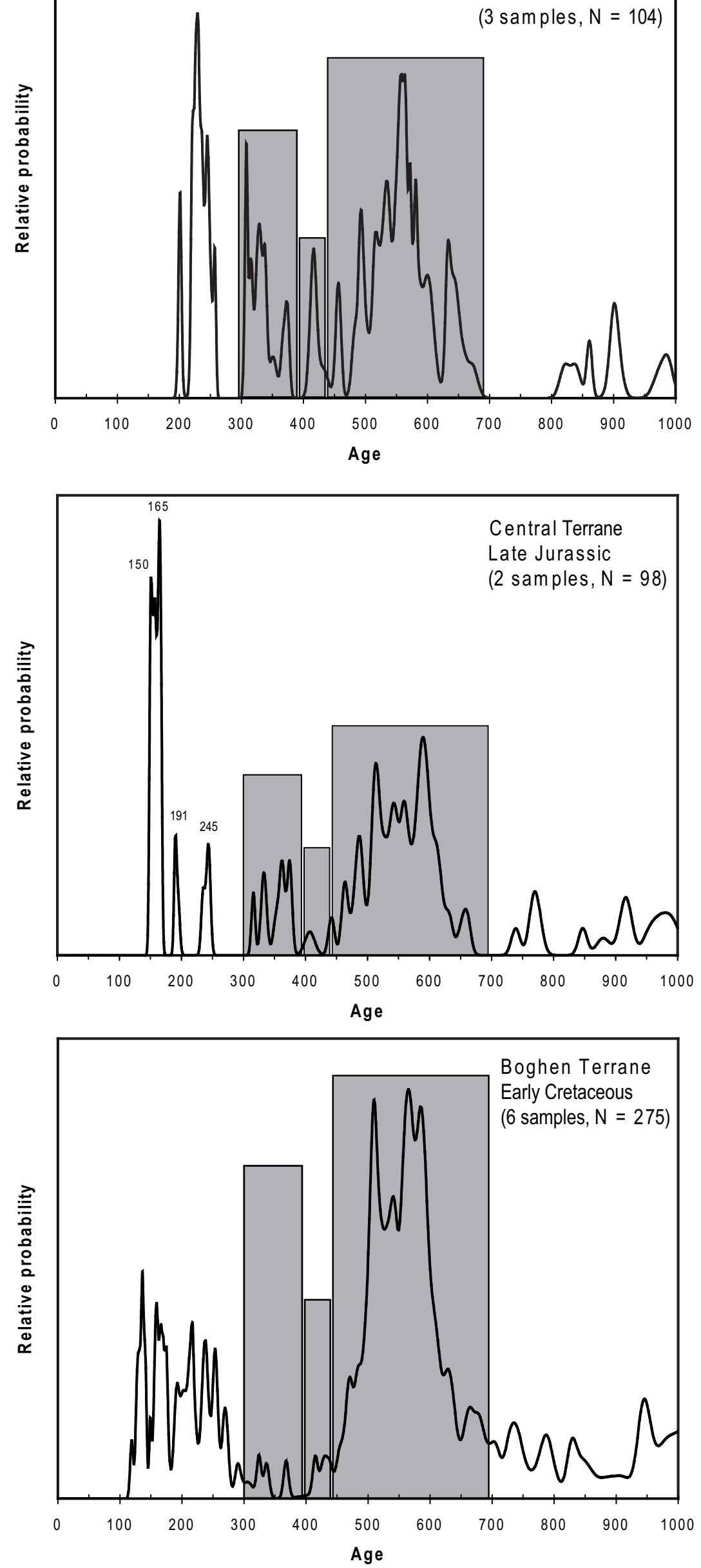

Figure 7: Compared detrital zircon populations of Central and Boghen terranes 


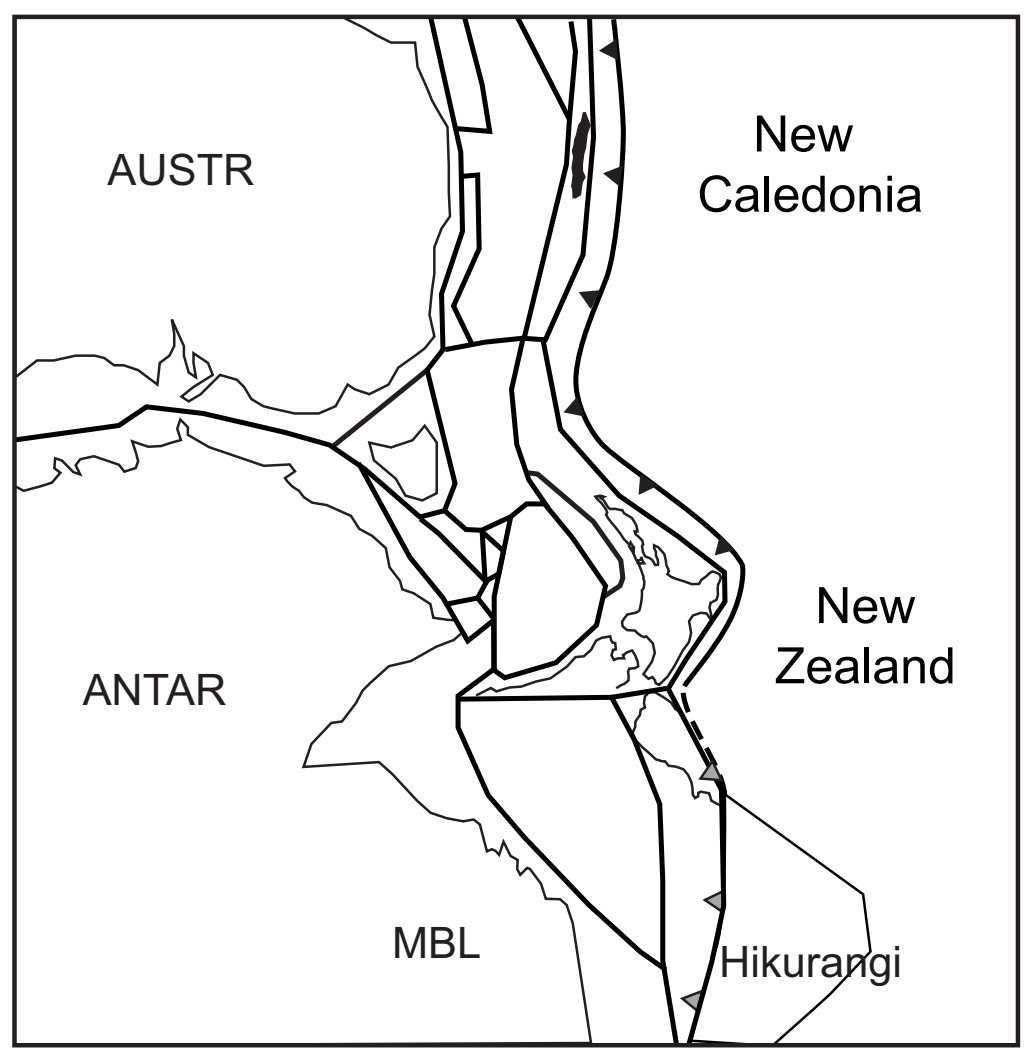

Figure 8: reconstruction of the Australian margin near the end of the Early Cretaceous

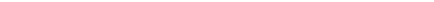




\section{Figure captions}

Figure 1: Geological sketch map of New Caledonia showing the three basement terranes, the Late Cretaceous Formation à charbon, and Diahot Terrane. Labels refer to the sampling localities as on Table 1, and to probability density diagrams (Figs 4 and 5).

Figure 2: Stratigraphy of the Late Cretaceous syn-rift and Paleocene-Eocene post-rift sequence of New Caledonia (autochthonous cover only)

Figure 3: Probability density diagram for detrital zircon age populations of the Late Cretaceous sandstones (all samples) to show the prominent Cretaceous population and minor older components of Early Mesozoic, Early Paleozoic and Precambrian age. Note that the youngest zircons (ca. $78 \mathrm{Ma}$ ) are related to one single sample (BOU 12) coming from the upper part of the sequence (Campanian)

Figure 4: Probability density diagram for the age of detrital zircons from the Late Cretaceous sandstones restricted to the 70-140 Ma interval to show the calculated medians of the eight Cretaceous populations (using the Isoplot 3 software of Ludwig 2003).

Figure 5: Probability density diagrams for detrital zircon age populations of the individual samples of the autochthonous Formation a Charbon. Note the gray line on the diagram for the sample "Temala” which contrasts the Late Cretaceous age pattern (in black) with that of the underlying sandstones of the Boghen Terrane (gray) from Cluzel et al. 2010..

Figure 6: Probability density diagrams for detrital zircon age populations of the individual samples of the Diahot metamorphic terrane.

Figure 7: Composite probability density diagrams for detrital zircon age populations of the sandstones of Central (Triassic and Jurassic) (Adams et al., 2009b) and Boghen terranes. The gray boxes are based upon the main Proterozoic and Paleozoic zircon populations of the Triassic sandstones of the Central terrane in order to compare it to the Jurassic of the same terrane (very similar), and that of the Boghen Terrane (somewhat different). 
Figure 8: Very simplified configuration of the Australian margin in early Late Cretaceous time (modified from Gaina et al. 1998; Sutherland 1999; and Hall 2002) to show the location of New Caledonia within Zealonia with respect to Australia and Antarctica. There is still some uncertainty on the precise limits of continental fragments due to the Cretaceous stretching of continental crust.

Figure 9: A tentative reconstruction of the Australian margin during the 130-83 Ma period showing the diachronous eastward propagating thinning/rifting of the Australian crust and the Campanian (ca. $83 \mathrm{Ma}$ ) final break-off (for a review of time-constraints, see Cluzel et al., 2010 and references therein). According to this model, no Australian sedimentary transit could reach New Caledonia since 130-120 Ma.

\section{Appendix I: Technical details Appendix I Technical details}

Stages names and limits used in the text refer to the New Zealand timescale of Cooper (2004) and G.S.A. geological timescale of Walker and Geissman (2009).

\section{Zircon dating at GEMOC (CJA)}

To minimise sample handling for zircon recovery, a $1 \mathrm{~kg}$ sample was collected at the field outcrop as 5 mm-size gravel, removing all weathered rinds, blemishes, inclusions and joint faces. This enabled direct crushing in a tungsten carbide swingmill 2-3 times, for 5-10 seconds, sieving at each stage through a single, 250 micron mesh sieve. The sieved material was washed and decanted several times in water, to remove mud-size fractions, thus retaining a 200-300 g sample in a 30-250 micron size range, which was then dried. A heavy mineral concentrate was obtained from a $100 \mathrm{~g}$ portion in sodium polytungstate liquid, adjusted to a specific gravity of 2.95-2.98, from which about 500 zircon grains were then hand-picked as randomly as possible, i.e. taking all grains within a $1 \mathrm{~mm}$ microscope stage field of view. Of these, 50-100 grains were mounted in resin to be polished for LAICPMS (laser-ablation inductively-coupled plasma-source mass spectrometry) analysis.

Analytical protocols relating to ablation procedures, mass spectrometric analysis and data treatment are discussed in detail in Jackson et al. (2004). These authors' preferred 
procedures were followed in this work, using a Merchantek pulsed Nd-YAG laser, frequency-quintupled to operate at $213 \mathrm{~nm}$, and an Agilent 7500S ICPMS instrument.

In all cases, the ablated spot size was in the range 30-50 microns, with the ablation time about 60 seconds, preceded by 60 seconds background measurement, and followed by 60-120 seconds washout. Groups of 10-12 zircon sample grain analyses were preceded and followed by duplicate analyses of firstly, the in-house zircon standard GJ-1, and secondly, by 1-2 analyses each of the international zircon standards, MT-1 and 91500. The GLITTER data interpretation software package (www.els.mq.edu.au/GEMOC/) enabled analysis of $U$, $\mathrm{Pb}$ and Th absolute count rates, and all relevant isotopic ratios, during the run cycle, and the elimination of unstable beam intervals, and rejection of data where zircon core regions were inadvertently encountered.

Using the laser spot size of 30-50 microns enabled age measurements to be made adjacent to crystal margins, rather than cores, and preferably, close to crystal terminations (as defined by two crystal edges). Isotopic data were continually monitored during ablation to check that zircon cores were not being intersected. Efficient use of the instrument time dictated that strongly unimodal patterns were investigated only to analysis totals of $\mathrm{N}=33$ 50, bimodal patterns to $\mathrm{N}=50-70$, and strongly polymodal patterns to $\mathrm{N}=100$ (N.B. throughout this work ' $N$ ' and ' $\mathrm{n}$ ' refer to dataset totals and subgroups respectively). This allowed significant age groups (n) comprising $>10 \%$ to be revealed by three or more analyses (Andersen, 2005).

Full 207Pb/206Pb, 206Pb/238U, 207Pb/235U, and 208Pb/232Th age data (and 1 standard errors) are listed in the Appendix II. All ages used here are 206 Pb/238U zircon ages where $<1000 \mathrm{Ma}$, and $207 \mathrm{~Pb} / 206 \mathrm{~Pb}$ ages where $>1000 \mathrm{Ma}$. A small minority of the analyses have common $\mathrm{Pb}$ corrections (using protocols of Andersen, 2002). Age groupings, were determined by visual inspection of probability density plots of zircon age sets, using deconvolution (and weighted average) algorithms in the ISOPLOT-Ex (version 3.0) software (kindly provided by K. Ludwig, United States Geological Survey).

\section{Zircon dating at Hobart (SM)}

The LA-ICPMS method is now widely used for measuring $\mathrm{U}$, Th and $\mathrm{Pb}$ isotopic data (e.g. Fryer et al. 1993; Compston 1999; Black et al. 2003; Kosler \& Sylvester 2003, Black et al. 2004; Jackson et al. 2004, Chang et al. 2006 Harley \& Kelly 2007). 
Approximately $100 \mathrm{~g}$ of rock was repeatedly sieved and crushed in a Cr-steel ring mill to a grain size $<400$ micron. Non magnetic heavy minerals were then separated using a gold pan and a Fe-B-Nd hand magnet. The zircons were hand picked from the heavy mineral concentrate under the microscope in cross-polarised transmitted light. The selected crystals were placed on double sided sticky tape and epoxy glue was then poured into a $2.5 \mathrm{~cm}$ diameter mould on top of the zircons. The mount was dried for 12 hours and polished using clean sandpaper and a clean polishing lap. The samples were then washed in distilled water in an ultrasonic bath.

The analyses in this study were performed on an Agilent 7500cs quadrupole ICPMS with a $193 \mathrm{~nm}$ Coherent Ar-F gas laser and the Resonetics M50 ablation cell at the University of Tasmania in Hobart. The downhole fractionation, instrument drift and mass bias correction factors for $\mathrm{Pb} / \mathrm{U}$ ratios on zircons were calculated using 2 analyses on the primary (91500 standard of Wiendenbeck et al. 1995) and 1 analysis on each of the secondary standard zircons (Temora standard of Black et al. 2003 \& JG1 of Jackson et al. 2004) analysed at the beginning of the session and every 12 unknown zircons (roughly every $1 / 2$ hour) using the same spot size and conditions as used on the samples. Additional secondary standards (The Mud Tank Zircon of Black \& Gulson 1978) were also analysed. The correction factor for the $207 \mathrm{~Pb} / 206 \mathrm{~Pb}$ ratio was calculated using 3 large spot of NIST610 analysed at the beginning and end of the day and corrected using the values recommended by Baker et al. (2004).

Each analysis on the zircons began with a 30 second blank gas measurement followed by a further 30 seconds of analysis time when the laser was switched on. Zircons were sampled on 32 micron spots using the laser at $5 \mathrm{~Hz}$ and a density of approximately $1.5 \mathrm{~J} / \mathrm{cm} 2$. A flow of He carrier gas at a rate of 0.6 litres/minute carried particles ablated by the laser out of the chamber to be mixed with Ar gas and carried to the plasma torch. Elements measured include 49Ti, 96Zr, 146Nd, 178Hf, 202Hg, 204Pb, 206Pb, 207Pb, 208Pb, 232Th and 238U with each element being measured sequentially every $0.16 \mathrm{~s}$ with longer counting time on the $\mathrm{Pb}$ isotopes compared to the other elements. The data reduction used was based on the method outlined in detail in Meffre et al. (2008) similar to that outlined in Black et al. (2004) and Paton et al (2010) .

Element abundances on zircons were calculated using the method outlined by Kosler (2001) using $\mathrm{Zr}$ as the internal standard element, assuming stoichiometric proportions and using the 91500 to standard correct for mass bias. 
Appendix II: U-Pb detrital zircon age data 